\title{
A Systematic Review of Immersive Social Media Activities and Risk Factors for Sexual Boundary Violations among Adolescents
}

\author{
Arsad FS ${ }^{\mathrm{a}}$, Abdul Khani MIA ${ }^{\mathrm{a}}$, Daud F \\ ${ }^{a}$ Department of Community Health, Faculty of Medicine, UKM Medical Centre, Malaysia
}

\begin{abstract}
Social media is appealing to the general public, especially the teenagers. This has brought about changes as the role of social media has penetrated our daily activities which directly affects the adolescence. This review looked at the usage of social media amongst adolescents and its impact on their sexual behaviour. Four databases were used in the literature search ie Web of Science, PubMed, EBSCOhost, and Ovid Medline. The search terms used revolved around social media, adolescent and social behaviour. Only English literature published from 2015 to 2020 were included. A total of 244 potentially relevant articles were identified in the initial search. 16 were excluded due to duplicates. A further 199 articles were excluded due to irrelevant population, intervention or outcome. Only 29 articles were suitable for narrative synthesis. The selected articles were analysed for risk factors and impact on the usage of social media on sexual behaviour. Sexual abuse, same-sex sexual activity, pornography, multiple online sexual partner, and sexual dissatisfaction were found to be negative impact. Positive impact included understanding of sexual role and consequences, safe sex practices and improved psychological well-being. This systematic review proved social media usage amongst adolescents have great impact on their sexual behaviour. Sexting was the main social media online sexual activity amongst adolescents which brings about negative sexual behaviours. This must be curb from earlier on which demands parental supervision in monitoring adolescence online activities.
\end{abstract}

KEYWORDS: Social media, adolescent, sexual activities, sexting, behaviour

\section{INTRODUCTION}

Social media has become one of the must have services negative outcome if used in a wrong way. One of the for almost everybody, especially teenagers. Initially, negative impacts is the usage of social media for sexual internet was used to seek information and has minimal intentions. ${ }^{2}$

role for socializing. However, the trend has changed.

Social media is now a platform for almost everyone to communicate and perform businesses. ${ }^{1}$ Besides the Adolescence is a very crucial period. During this transition, adolescents are prone to being involved in convenience of getting the latest information in a split high-risk behaviours such as usage of social media for second, social media is also used to get to know people sexual satisfaction. This high-risk behaviour may lead to without needing or seeing them physically. This would many negative outcomes to the adolescents. Multiple help people to socialize and make new friends easier. studies showed that adolescents spend a few hours daily However, the advantages of social media can turn into a

on social media. 3,4 Some of the teenagers are exposed to sexual content which influences their sexual behaviour.

Corresponding Author:

Dr. Faiz Bin Daud

Department of Community Health,

Faculty of Medicine,

UKM Medical Centre, Malaysia.

Tel No: +6019-2712008

E-mail : faizdaud@ppukm.ukm.edu.my
It is very easy for adolescents to get access to social media since almost everyone owns a smartphone. The smartphone provides easy access to any social media platform and may influence the adolescents' sexual behaviour in the long run. The adolescents use the social 
media and show their sexual behaviour online. The influence of social media and friends are the most common factors associated with high-risk behaviour in the sexual context.

Social media provides the platform for the adolescents to expose themselves to sex related material in term of pictures, videos and others. The sexual content also applies to words that are being used in texting and posting a status on the social media applications.

The adolescents are easily exposed to sexual materials. Without proper supervision and self-control, more highrisk behaviour can occur amongst them. Some studies reported that teenagers that were exposed to sexual material online practised a high-risk behaviour such as sexting, pornography, online sexual abuse, and many more. ${ }^{5}$

This article aims to do a systematic review on the social media usage amongst adolescents and its impact on their sexual behaviour.

\section{METHODOLOGY}

\section{Search method}

Four different databases were used in the literature search which were Web of Science, PubMed, EbcoHost, and OvidMedline. The search term used were divided into three components which were social media, adolescent and social behaviour. Similar meanings of each component were used to broaden the literature search. The similar words being used are listed in the Table 1. 244 potentially relevant articles were identified in the first search. 16 were excluded due to duplicates. A further 199 were excluded due to irrelevant population, intervention or outcome. Finally, only 29 articles were analysed for narrative synthesis. Restrictions put in were studies published in English from 2015 until 2020. The literature search process is illustrated in Figure 1.

\section{Data collection and analysis}

In our systematic review, we included peer-reviewed publications, scientific book chapters, and online conference presentations, pertaining to social media
Table I: Search terms

\begin{tabular}{lllll}
\hline SOCIAL MEDIA & \multicolumn{2}{c}{ ADOLESCENT } & \multicolumn{2}{l}{ SEXUAL } \\
BEHAVIOUR
\end{tabular}

usage by adolescents for online sexual activity or containing inputs about the topic against the background of a different research question. Selected articles were published between 2015 and 2020, and were available in English or translated to English. Duplicates were removed from the list of all citations. Chosen titles and abstracts were evaluated. All articles that fulfilled the criteria were included for analysis.

\section{RESULTS}

The selected articles were analysed and risk factors for social media online sexual activities (OSA) among adolescents and its impacts were determined. The risk factors can be divided into themes which are sexting, sexual abuse, mental health, same-sex sexual activity, pornography, multiple online sexual partner, unsafe sex practices, and sexual dissatisfaction. Information related to adolescents will be discussed along with these classifications. Any risk factors and impacts on sexual behaviour among adolescent that related to the usage of social media are listed in the result.

\section{i. Sexting}

The behaviour of sending messages to another person with any type of sexual content is called sexting. ${ }^{6}$ Study in the United States on adolescents, stated that one of the outcomes of social media usage on sexual behaviour was sexting. ${ }^{1}$ Adolescents who practiced sexting are associated with distrust, emotional deprivation and grandiosity. 5 Sexting creates a pathway for adolescents to experience and explore sexuality despite their imagerelated issues as it provides better physical image control, allows sexter to disconnect emotionally, and be more confident. ${ }^{7}$ It was reported that $22 \%$ of at-risk 
adolescents (12-14 year-olds) were sexting higher than what was reported in the general population. 8,9 This showed that behavioural and emotional symptoms in this study may increase the likelihood of adolescents getting involved in sexting. ${ }^{10}$

Male users commonly use the social media for sexting. ${ }^{11}$ Few risk factors identified in the study were limited capacity of self-regulation, peer pressure and experimentation by the adolescents. Study in Australia also showed similar outcome which was sexting among the adolescents. ${ }^{12}$ The risk factor identified was the rapid communication technology especially the smartphone related with the large increase in sexting. Maltreated youths were also at risk for online sexual content exposure and translated into high-risk sexual behaviour such as sexting. ${ }^{13}$ Sexting among adolescents is now rampant. The United Kingdom has emphasised that risk minimization method compared to abstinence approach would be the most suitable way forward. ${ }^{14}$ It is recommended that providing support to adults gives them more confident in guiding adolescents through their online interactions. Online programs may provide an important role in lowering the risks associated with sexting by empowering adolescents and adults to have improved communication regarding sexting and online safety. ${ }^{15}$

\section{ii. Sexual Abuse}

Dating abuse is defined as a repetitive pattern of verbal, physical and sexual abuse, and aggressiveness such as controlling actions and jealousy among adolescents and young adults. ${ }^{16}$ Since the usage of digital media viz. mobile phones and social media, amongst adolescents has increased, the risk that such media being used as a tool for dating abuse has also increase. Both digital and traditional forms of abuse are strongly positively correlated. ${ }^{17-19}$ The internet exposes the adolescents to cyberbullying and to meet sexual abusers while they surf the internet to get to know new people. ${ }^{20-23} 13.7 \%$ of female adolescents and $9.2 \%$ of males were reported to experience online sexual abuse in flirty type relationships. ${ }^{20}$ In addition, a study on adolescents showed a rate of online victimhood as high as $27.0 \%$ and a rate of sexual abuse of $5.0 \%$ in males and $16.0 \%$ in females. ${ }^{21}$ One literature reported $48.1 \%$ of $14-20$ year-old adolescents faced digital dating abuse in the past 2 months. ${ }^{24}$ Another reported $46 \%$ of high school students had committed digital dating abuse. ${ }^{25}$ There is also a strong positive correlation between digital dating abuse victimization and perpetration. ${ }^{26-27}$

High-risk sexual behaviour from the usage of social media can also result in sexual abuse. Study showed that most of the victims of sexual abuse were exposed to sexual penetration and physical abuse. ${ }^{4}$ Lack of sexual education from the parents was identified as one of the risk factors. This sexual behaviour also contributed in the increasing cases of sexual workers among the adolescents. ${ }^{28}$ Online shaming on social media is also a form of sexual abuse carried out by the users to satisfy their sexual needs. ${ }^{29}$ Relationship among the partners can be affected with jealousy such as online pictures of the partner with others and online messaging with others. ${ }^{29}$ This can lead to sexual abuse by the partner who was angered by the flirtatious partner's online or physical acts. It was also reported in a study that digital sexual abuse contributes to $42.7 \%$ of victimization and $29.1 \%$ perpetration and half of the studied sample experienced digital direct aggression viz. $59.2 \%$ victimization and $48.3 \%$ perpetration. ${ }^{30}$

\section{iii. Same-sex Sexually Active}

Same-sex sexual activity is serious and important especially in the transmission of diseases from sexual activities. It stated that social media may influenced the male users to engage in sex with other male. ${ }^{2}$ Nowadays, increasing trend of HIV positive patients amongst sexual active gay is very significant worldwide. Another study among adolescents in USA showed similar finding. ${ }^{31}$ The study showed more than half of newly diagnosed male sex with male (MSM) had online sexual partners 12 months prior to their diagnosis. This phenomenon is strongly related to the usage of social media. The adolescents are especially at risk for this negative behaviour. Study among adolescents in USA showed limited sexual education in school, and family based sexual education were identified as the risk factors. ${ }^{2}$ Smartphone applications (apps) assisted sexual partner seek sexual gender minorities (SGM) which includes gays worldwide. ${ }^{32-34}$ The apps allowed these users to explore their sexual appetite, reach sexual appeal, and associate with the SGM communities. ${ }^{35-37}$ It was also noted that smartphone apps usage has been 


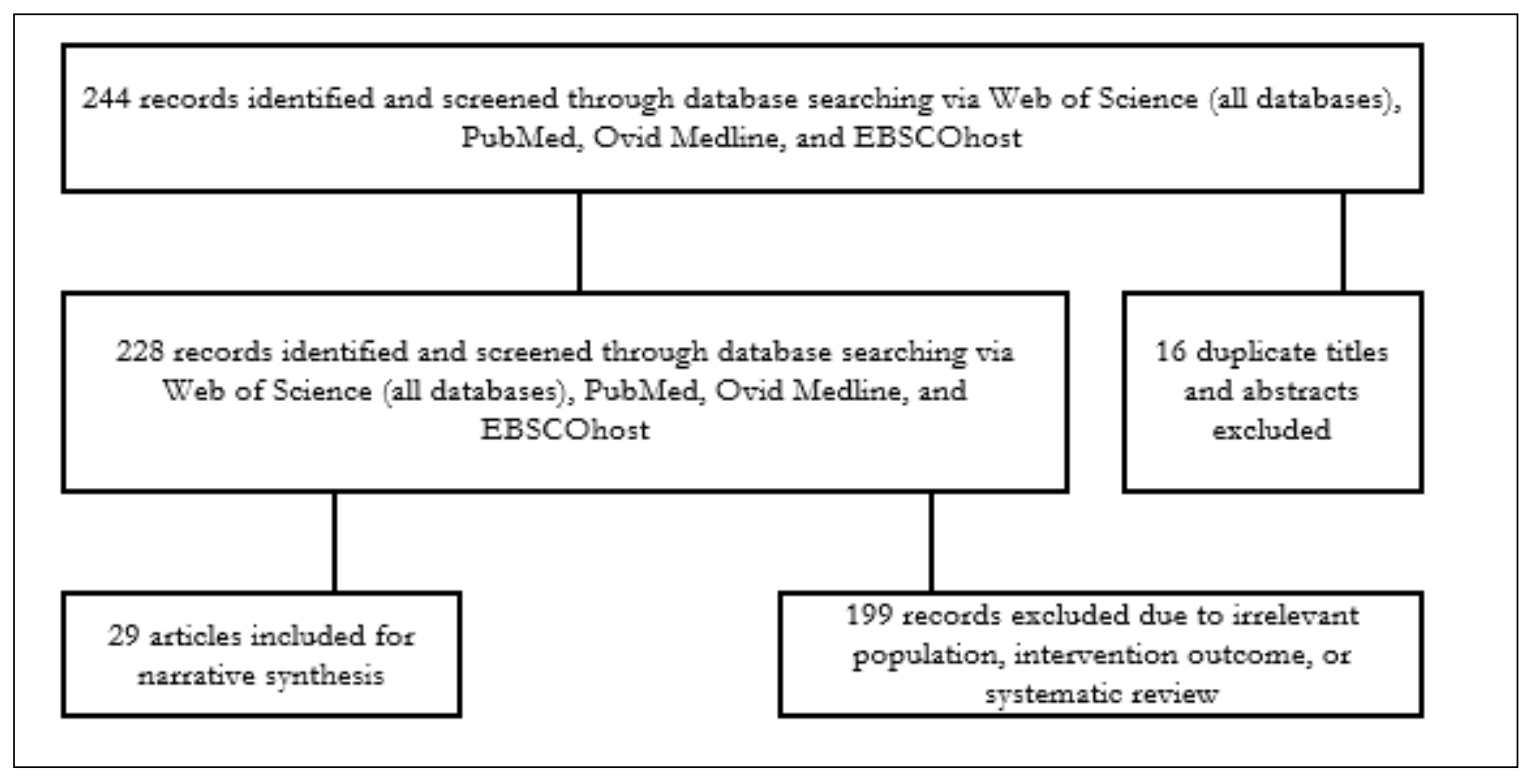

Figure 1: Flow chart of literature search process

linked with higher accounts of sexual health awareness such as HIV testing among the SGMs. ${ }^{33,38,39}$ Recent studies reported that a majority of SGMs used sexual networking apps which are designated for sexual minority male adults. The same study also showed that the apps used was linked to both risk perceptions and behaviours (eg: greater perceived HIV risk with more partners) and also protective behaviours (eg: already tested for HIV). ${ }^{40}$

\section{iv. Mental health}

The usage of social media can also affect the mental health of the adolescents. Young people use texting as a conduit for getting reviews and reinforcing their body image. ${ }^{7,41}$ The female adolescents seem to be more affected by their smartphone usage. ${ }^{42}$ The dependency on smartphone for social media use decreases the vitality and mental health. Study in Italy showed that problematic social media usage was more likely to present with mental health problem. ${ }^{43}$ Some of the examples of mental health issues related to problematic social media usage were narcissism, loneliness and selfdiscrepancy. From a study, the actions in social media such as posting narcissistic selfies, characterized by grandiose exhibitionism and vanity, is thought to be and evolutionary adaptive self-promotion mechanism. It explains narcissism as the force for selfie-posting, drawn from the Freudian evolutionary psychology. ${ }^{44}$ The sexual information gained from the social media applications translated into real act and becomes their new behaviour. ${ }^{45}$ A study stated that female users develop their autonomy on their sexual control even with monitoring from their parents. ${ }^{46}$ Meanwhile, parents with marital conflict and history of being abused during childhood, can experience mental health problem and tend to become abusive to their children. ${ }^{47} \mathrm{~A}$ research which focuses on females, concludes that sexual objectification of adolescence in general is linked with depression, low self-esteem, eating distress, and negative body image. ${ }^{48}$

Adolescents show an increase anxiety level, especially when they are cyberbullied and fear of having sexual transmitted diseases (STD). ${ }^{12}$ Social media usage and several mental health symptoms such as anxiety, depression, low self-esteem may lead to catastrophic outcome such as suicidal ideation. ${ }^{12}$ Impaired mental health from the impact of social media has shown a linkage to significant implication towards unprotected sex and pre-marital sex among adolescents. ${ }^{1}$ Having multiple partners along with substance abuse such as alcohol and drugs during sex may also occur. ${ }^{1}$ Thus, the risk for contracting STD and HIV will be higher from such actions.

Pornography addiction from the exposure of sex explicit materials from the social media can have a negative influence on adolescents' attitude and mental health. The adolescents are at risk of high-risk behaviours such as multiple sexual partners, sexual violence and harassment from the pornographic materials that 
Table II: Summary of findings on social media usage on sexual behaviour among adolescent

\begin{tabular}{|c|c|c|c|c|c|}
\hline No & Author & Title & Year & Country & Key Findings \\
\hline 1 & $\begin{array}{l}\text { American College of, } \\
\text { Obstetricians Gynaecologists' } \\
\text { Committee on Adolescent } \\
\text { Health Care }\end{array}$ & $\begin{array}{l}\text { Committee Opinion } \\
\text { No. 653: Concerns } \\
\text { regarding social media } \\
\text { and health issues in } \\
\text { adolescents and young } \\
\text { adults }\end{array}$ & 2016 & USA & $\begin{array}{l}\text { Risk factors: } \\
\text { limited capacity of self-regulation, peer pressure, } \\
\quad \text { experimentation, cyberbullied } \\
\text { Outcome: } \\
\text { sexting, pornography, online dating, STI, unwanted } \\
\text { pregnancy } \\
\text { social media as platform to connect with friends and } \\
\text { improve adolescent socialisation skills } \\
\text { high schools' students used social media as a regular } \\
\text { resource to search health information } \\
\text { Management: } \\
\text { multidisciplinary approach, mental health referral }\end{array}$ \\
\hline 2 & $\begin{array}{l}\text { Arrington-Sanders R, } \\
\text { Harper GW, } \\
\text { Morgan A, } \\
\text { Ogunbajo A, } \\
\text { Trent M, Fortenberry JD. }\end{array}$ & $\begin{array}{l}\text { The role of sexually } \\
\text { explicit material in the } \\
\text { sexual development of } \\
\text { same-sex-attracted } \\
\text { black adolescent males }\end{array}$ & 2015 & USA & $\begin{array}{l}\text { Risk factors: } \\
\text { limited school education, lack of family-based sex } \\
\text { education } \\
\text { Outcome: } \\
\text { Same sex sexually active } \\
\text { Gaining knowledge on sexual organ function } \\
\text { Understanding the sexual role, responsibility, and } \\
\text { consequences } \\
\text { Management: } \\
\text { comprehensive sexually education programs, } \\
\text { development of internet-based HIV/STI prevention } \\
\text { strategies targeting the group }\end{array}$ \\
\hline 3 & $\begin{array}{l}\text { Burkhart LE, Hoopes AJ, } \\
\text { Moreno M. }\end{array}$ & $\begin{array}{l}\text { Why is this person } \\
\text { writing this stuff on } \\
\text { Facebook? Female } \\
\text { college students' } \\
\text { perceptions of sexual } \\
\text { reference displays on } \\
\text { Facebook }\end{array}$ & 2017 & USA & $\begin{array}{l}\text { Outcome: } \\
\text { social networking sites (SNS) are popular; adolescents } \\
\text { and young adults can display sexual content. } \\
\text { females' perceived link between online and offline } \\
\text { sexual behaviour } \\
\text { Management: } \\
\text { future studies should investigate potential interventions } \\
\text { to avoid negative consequences from online } \\
\text { miscommunication }\end{array}$ \\
\hline 4 & $\begin{array}{l}\text { Chan PA, } \\
\text { Towey C, } \\
\text { Poceta J, } \\
\text { Rose J, } \\
\text { Bertrand T, } \\
\text { Kantor R, } \\
\text { Harvey J, } \\
\text { Santamaria EK, } \\
\text { Alexander-Scott N. } \\
\text { Nunn A. }\end{array}$ & $\begin{array}{l}\text { Online hook-up sites } \\
\text { for meeting sexual } \\
\text { partners among men } \\
\text { who have sex with } \\
\text { men in Rhode Island, } \\
\text { 2013: A call for public } \\
\text { health action }\end{array}$ & 2016 & USA & $\begin{array}{l}\text { Outcome: } \\
\text { more than half }(60 \%, 26 / 43) \text { of newly diagnosed MSM } \\
\text { reported meeting sexual partners online in the } 12 \\
\text { months prior to their diagnosis } \\
\text { partnership with the hook-up site for delivering } \\
\text { messaged of HIV prevention }\end{array}$ \\
\hline 5 & $\begin{array}{l}\text { Collins RL, } \\
\text { Strasburger VC, } \\
\text { Brown JD, } \\
\text { Donnerstein E, } \\
\text { Lenhart A, } \\
\text { Ward LM. }\end{array}$ & $\begin{array}{l}\text { Sexual media and } \\
\text { childhood well-being } \\
\text { and health }\end{array}$ & 2017 & USA & $\begin{array}{l}\text { Outcome: } \\
\text { sexual displays on social media sites are related to } \\
\text { problematic beliefs and behaviours, online } \\
\text { pornography appears to be more problematic for } \\
\text { youth than off-line sources } \\
\text { Management: } \\
\text { policy makers should stimulate the development of } \\
\text { such interventions, including tools to help parents } \\
\text { identify and manage negative media influences on } \\
\text { their children's sexual well-being and development } \\
\text { and dissemination of innovative media literacy } \\
\text { programs related to sexual health. }\end{array}$ \\
\hline 6 & $\begin{array}{l}\text { Díaz-Bustamante-Ventisca M, } \\
\text { Llovet-Rodríguez C. }\end{array}$ & $\begin{array}{l}\text { Empowerment or } \\
\text { impoverishme-nt of } \\
\text { children from social } \\
\text { networks? Perceptions } \\
\text { of sexualized images of } \\
\text { girls in Instagram }\end{array}$ & 2017 & Spain & $\begin{array}{l}\text { Outcome: } \\
\text { sexualization of girls in social networks generates } \\
\text { perceptions that undervalue girls in intellectual, } \\
\text { social, and moral aspects }\end{array}$ \\
\hline
\end{tabular}




\begin{tabular}{|c|c|c|c|c|c|}
\hline 7 & $\begin{array}{l}\text { Dir AL, } \\
\text { Cyders MA }\end{array}$ & $\begin{array}{l}\text { Risks, risk factors, and } \\
\text { outcomes associated } \\
\text { with phone and } \\
\text { internet sexting among } \\
\text { university students in } \\
\text { the United States }\end{array}$ & 2015 & USA & $\begin{array}{l}\text { Outcome: } \\
\text { viability of personality and expectancies affecting sexual } \\
\text { hook-up behaviours through engagement in sexting } \\
\text { behaviours } \\
\text { positive behavioural outcomes in relationship such as } \\
\text { excited and happy when communicating via social } \\
\text { media }\end{array}$ \\
\hline 8 & $\begin{array}{l}\text { Fongkaew W, } \\
\text { Fongkaew K. }\end{array}$ & $\begin{array}{l}\text { My space, my body, } \\
\text { my sexual subjectivity: } \\
\text { Social media, sexual } \\
\text { practice and parental } \\
\text { control among teenage } \\
\text { girls in urban Chiang } \\
\text { Mai }\end{array}$ & 2016 & Thailand & $\begin{array}{l}\text { Outcome: } \\
\text { young women achieve a certain level of sexual } \\
\text { autonomy and construct their own sexual selves in } \\
\text { modern Northern Thai society, despite their parents' } \\
\text { attempts to prevent this. } \\
\text { Management: } \\
\text { development of future programmes on sexual health } \\
\text { promotion, parental skills and sexual communication } \\
\text { between Thai parents and their children }\end{array}$ \\
\hline
\end{tabular}

\begin{tabular}{|c|c|c|c|c|c|}
\hline 9 & $\begin{array}{l}\text { Gutierrez-Puertas L, } \\
\text { Marquez-Hernandez V, } \\
\text { Gutierrez-Puertas V, } \\
\text { Granados-Gamez G, } \\
\text { Rodriguez-Garcia MC. }\end{array}$ & $\begin{array}{l}\text { Online sexual activities } \\
\text { among university } \\
\text { students: Relationship } \\
\text { with sexual satisfaction }\end{array}$ & 2020 & Spain & $\begin{array}{l}\text { Outcome: } \\
\text { frequent online sexual activities were searching for } \\
\quad \text { sexual issues, flirting via chat rooms and viewing } \\
\quad \text { erotic or pornographic videos } \\
\text { platform to search info regarding unwanted pregnancy, } \\
\quad \text { menstruation, and contraception option }\end{array}$ \\
\hline & & & & & $\begin{array}{l}\text { Management: } \\
\text { necessary to conduct new research that delves into the } \\
\text { different ways in which the internet can influence } \\
\text { sexual satisfaction. }\end{array}$ \\
\hline 10 & Seunga Venus Jin, Ehri Ryu & $\begin{array}{l}\text { "The paradox of } \\
\text { narcissus and echo in } \\
\text { the Instagram pond" n } \\
\text { light of the selfie } \\
\text { culture from Freudian } \\
\text { evolutionary } \\
\text { psychology: self-loving } \\
\text { and confident but } \\
\text { lonely }\end{array}$ & 2018 & USA & $\begin{array}{l}\text { Outcome: } \\
\text { looking for social media popularity } \\
\text { integrative model of narcissism and reveal dynamic } \\
\text { relationships among users' narcissism, self- } \\
\text { discrepancy, self-confidence, intrasexual competition } \\
\text { for mates, need to belong, need for popularity, } \\
\text { loneliness, number of selfie/groupie posts on } \\
\text { Instagram, and number of Instagram followers/ } \\
\text { followings }\end{array}$ \\
\hline
\end{tabular}

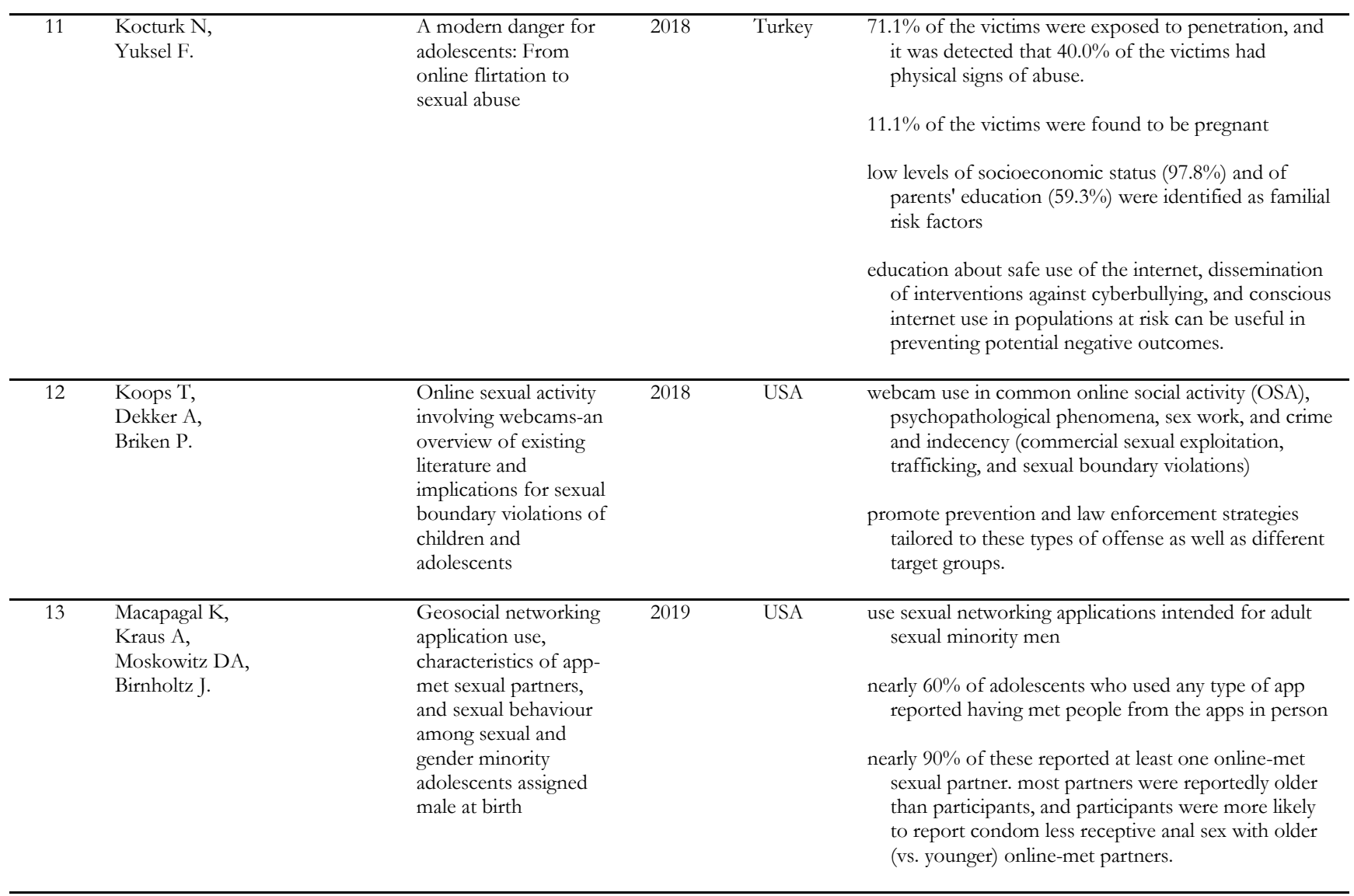




\begin{tabular}{|c|c|c|c|c|c|}
\hline 14 & $\begin{array}{l}\text { Macapagal K, } \\
\text { Moskowitz DA, } \\
\text { Li DH, } \\
\text { Carrion A, } \\
\text { Bettin E, } \\
\text { Fisher CB, } \\
\text { Mustanski B. }\end{array}$ & $\begin{array}{l}\text { Hookup app use, } \\
\text { sexual behaviour, and } \\
\text { sexual health among } \\
\text { adolescent men who } \\
\text { have sex with men in } \\
\text { the united states }\end{array}$ & 2018 & USA & $\begin{array}{l}\text { geosocial networking applications (e.g., "hook up } \\
\text { apps") are widely used among adult men who have } \\
\text { sex with men (MSM) } \\
\text { hook-up applications provide information such as } \\
\text { condom usage and knowledge of HIV and STI } \\
\text { further research should investigate a MSM's app-related } \\
\text { sexual and HIV/sexually transmitted infection } \\
\text { prevention decision-making to guide sexual health } \\
\text { education efforts for MSM }\end{array}$ \\
\hline 15 & $\begin{array}{l}\text { Marino C, } \\
\text { Hirst CM, } \\
\text { Murray C, } \\
\text { et al }\end{array}$ & $\begin{array}{l}\text { Positive mental health } \\
\text { as a predictor of } \\
\text { problematic internet } \\
\text { and Facebook use in } \\
\text { adolescents and young } \\
\text { adults }\end{array}$ & 2018 & Italy & $\begin{array}{l}\text { Positive mental health is negatively linked to both } \\
\text { Problematic Internet Use (PIU) and Problematic } \\
\text { Facebook Use (PFU) }\end{array}$ \\
\hline 16 & $\begin{array}{l}\text { Milton AC, } \\
\text { Gill BA, } \\
\text { Davenport TA, } \\
\text { Dowling M, } \\
\text { Burns JM, } \\
\text { Hickie IB. }\end{array}$ & $\begin{array}{l}\text { Sexting, web-based } \\
\text { risks, and safety in two } \\
\text { representative national } \\
\text { samples of young } \\
\text { Australians: } \\
\text { Prevalence, } \\
\text { perspectives, and } \\
\text { predictors }\end{array}$ & 2019 & Australia & $\begin{array}{l}\text { rapid uptake of information and communication } \\
\text { technology (ICT) over the past decade-particularly } \\
\text { the smartphone-has coincided with large increases in } \\
\text { sexting } \\
\text { multifaceted approach, where sexting is positioned } \\
\text { within a wider proactive conversation about gender, } \\
\text { culture, psychosocial health, and respecting and } \\
\text { caring for each other when on the web. }\end{array}$ \\
\hline 17 & Morelli M. & $\begin{array}{l}\text { Sexting, psychological } \\
\text { distress and dating } \\
\text { violence among } \\
\text { adolescents and young } \\
\text { adults }\end{array}$ & 2016 & Italy & $\begin{array}{l}\text { males (vs. females) did more sexting } \\
\text { non-heterosexuals (vs. heterosexuals) were more } \\
\text { involved in sexting } \\
\text { high/moderate users of sexting committed more offline } \\
\text { and online dating violence. } \\
\text { social media helps in facilitate communication and } \\
\text { relationships, improve psychological and social- } \\
\text { emotional well-being } \\
\text { protective factor against social stigma, prejudice, and } \\
\text { discrimination }\end{array}$ \\
\hline
\end{tabular}

\begin{tabular}{|c|c|c|c|c|c|}
\hline 18 & Naezer M. & $\begin{array}{l}\text { From risky behaviour } \\
\text { to sexy adventures: } \\
\text { Reconceptual-ising } \\
\text { young people's online } \\
\text { sexual activities }\end{array}$ & 2018 & Nether-land & $\begin{array}{l}\text { anxieties have been fuelled by the increasing popularity } \\
\text { of social media and practices such as sexting and } \\
\text { watching sexually explicit' materials online. }\end{array}$ \\
\hline 19 & Negriff S, Valente TW. & $\begin{array}{l}\text { Structural } \\
\text { characteristics of the } \\
\text { online social networks } \\
\text { of maltreated youth } \\
\text { and offline sexual risk } \\
\text { behaviour }\end{array}$ & 2018 & USA & $\begin{array}{l}\text { maltreated youth are at risk for exposure to online } \\
\text { sexual content and high-risk sexual behaviour }\end{array}$ \\
\hline 20 & $\begin{array}{l}\text { Papp LJ, } \\
\text { Hagerman C, } \\
\text { Gnoleba MA, } \\
\text { Erchull MJ, } \\
\text { Liss M, } \\
\text { Miles-Mclean H, } \\
\text { Robertson CM }\end{array}$ & $\begin{array}{l}\text { Exploring perceptions } \\
\text { of slut-shaming on } \\
\text { Facebook: Evidence } \\
\text { for a reverse sexual } \\
\text { double standard }\end{array}$ & 2015 & USA & $\begin{array}{l}\text { male 'sluts' were judged more harshly, 'shamer' was } \\
\text { negatively evaluated, especially when shaming a } \\
\text { woman }\end{array}$ \\
\hline 21 & $\begin{array}{l}\text { Pineda CO, } \\
\text { Torres CA, } \\
\text { Carreno TP, } \\
\text { Rodriguez RA. }\end{array}$ & $\begin{array}{l}\text { Sexting and its } \\
\text { relationship with early } \\
\text { maladaptive schemes } \\
\text { in adolescents }\end{array}$ & 2019 & Ecuador & $\begin{array}{l}\text { teenagers exchanging sexual material through electronic } \\
\text { devices have experienced the following factors } \\
\text { associated with sexting: abandonment }(\mathrm{p}<0.001) \text {, } \\
\text { insufficient self-discipline }(\mathrm{p}<0.001) \text {, distrust, abuse, } \\
(\mathrm{p}<0.037) \text {, emotional deprivation }(\mathrm{p}<0.005) \text {, self - } \\
\text { sacrifice }(\mathrm{p}<0.028) \text { 028), inflexible standard } 1 / \text { self- } \\
\text { demand }(\mathrm{p}<0.005) \text { and grandiosity }(\mathrm{p}<0.001)\end{array}$ \\
\hline 22 & $\begin{array}{l}\text { Pizzol D, Bertoldo A, } \\
\text { Foresta C. }\end{array}$ & $\begin{array}{l}\text { Adolescents and web } \\
\text { porn: a new era of } \\
\text { sexuality }\end{array}$ & 2016 & Italy & $\begin{array}{l}\text { among those surveyed, } 1163(77.9 \%) \text { of internet users } \\
\text { admit to the consumption of pornographic material, } \\
\text { and of these, } 93(8 \%) \text { access pornographic websites } \\
\text { daily, } 686(59 \%) \text { boys accessing these sites perceive } \\
\text { the consumption of pornography as always } \\
\text { stimulating, } \\
\text { educate web users, especially young users, to a safe and } \\
\text { responsible use of the internet and of its contents. }\end{array}$ \\
\hline
\end{tabular}




\begin{tabular}{|c|c|c|c|c|c|}
\hline 23 & $\begin{array}{l}\text { Reed LA, } \\
\text { Conn K, } \\
\text { Wachter K }\end{array}$ & $\begin{array}{l}\text { Name-calling, jealousy, } \\
\text { and break-ups: Teen } \\
\text { girls' and boys' worst } \\
\text { experiences of digital } \\
\text { dating }\end{array}$ & 2020 & USA & $\begin{array}{l}\text { media might play in dating abuse among adolescents } \\
\text { public insults, general insults, violations of privacy, } \\
\text { rumours, break-ups, and pressure for sex/sexual } \\
\text { photos were the most commonly reported worst } \\
\text { digital dating experiences. }\end{array}$ \\
\hline 24 & $\begin{array}{l}\text { Rice E, } \\
\text { Winetrobe H, } \\
\text { Holloway IW, } \\
\text { Montoya J, } \\
\text { Plant A, } \\
\text { Kordic T. }\end{array}$ & $\begin{array}{l}\text { Cell phone internet } \\
\text { access, online sexual } \\
\text { solicitation, partner } \\
\text { seeking, and sexual risk } \\
\text { behaviour among } \\
\text { adolescents }\end{array}$ & 2015 & USA & $\begin{array}{l}\text { students with cell phone internet access were more } \\
\text { likely to report being solicited online for sex, being } \\
\text { sexually active, and having sex with an internet-met } \\
\text { partner. } \\
\text { bisexual-identifying students reported higher rates of } \\
\text { being approached online for sex, being sexually } \\
\text { active, and not using condoms at last sex. } \\
\text { programs must target adolescents of all sexual } \\
\text { identities, as adolescents may not yet be "out," and } \\
\text { bisexual and gay adolescents are more likely to } \\
\text { engage in risky sex behaviours. }\end{array}$ \\
\hline 25 & $\begin{array}{l}\text { Seal DW, } \\
\text { Benotsch EG, } \\
\text { Green M, } \\
\text { Snipes DJ, } \\
\text { Bull SS, } \\
\text { Cejka A, } \\
\text { Lance SP, } \\
\text { Nettles CD. }\end{array}$ & $\begin{array}{l}\text { The use of internet } \\
\text { chat rooms to meet } \\
\text { sexual partners: A } \\
\text { comparison of non- } \\
\text { heterosexually } \\
\text { identified men with } \\
\text { heterosexually } \\
\text { identified men and } \\
\text { women }\end{array}$ & 2015 & USA & $\begin{array}{l}\text { reasons for meeting people online, desired partner } \\
\text { characteristics, and the process of connecting for sex } \\
\text { paralleled those observed in face-to-face contexts } \\
\text { people used internet chat rooms to identify more } \\
\text { partners and specific partner characteristics. }\end{array}$ \\
\hline 26 & Stevens R. & $\begin{array}{l}\text { Social media use and } \\
\text { sexual risk reduction } \\
\text { behaviour among } \\
\text { minority youth: seeking } \\
\text { safe sex information }\end{array}$ & 2017 & $\overline{\text { USA }}$ & $\begin{array}{l}\text { sexual health is an important area of study-particularly } \\
\text { for minority youth and youth living in disadvantaged } \\
\text { neighbourhoods } \\
\text { health practitioners should utilize social media as an } \\
\text { important health promotion tool. }\end{array}$ \\
\hline 27 & $\begin{array}{l}\text { Van Ouytsel J, } \\
\text { Walrave M, } \\
\text { Ponnet K, } \\
\text { Willems AS, } \\
\text { Van Dam M. }\end{array}$ & $\begin{array}{l}\text { Adolescents' } \\
\text { perceptions of digital } \\
\text { media's potential to } \\
\text { elicit jealousy, conflict } \\
\text { and monitoring } \\
\text { behaviours within } \\
\text { romantic relationships }\end{array}$ & 2019 & Belgium & $\begin{array}{l}\text { sources of jealousy within their romantic relationships, } \\
\text { such as online pictures of the romantic partner with } \\
\text { others and online messaging with others. }\end{array}$ \\
\hline 28 & Withers KL. & $\begin{array}{l}\text { The relationship } \\
\text { between the "dark } \\
\text { triad" personality traits } \\
\text { and deviant behaviour } \\
\text { on social networking } \\
\text { sites }\end{array}$ & 2017 & China & $\begin{array}{l}\text { incidents of spear-phishing, identity theft, and other } \\
\text { known cyber threats are becoming more } \\
\text { commonplace }\end{array}$ \\
\hline 29 & $\begin{array}{l}\text { Yang SY, } \\
\text { Lin CY, } \\
\text { Huang YC, } \\
\text { Chang JH }\end{array}$ & $\begin{array}{l}\text { Gender differences in } \\
\text { the association of } \\
\text { smartphone use with } \\
\text { the vitality and mental } \\
\text { health of adolescent } \\
\text { students }\end{array}$ & 2018 & Taiwan & $\begin{array}{l}\text { adolescent females are deeply affected by their } \\
\text { smartphone use. } \\
\text { smartphone dependence may decrease the vitality and } \\
\text { mental health of male adolescents. }\end{array}$ \\
\hline
\end{tabular}

showed the negative behaviours. ${ }^{1}$ A study reported higher frequency of masturbation amongst adolescent who were addicted to pornography. ${ }^{3}$

These examples will lead to the negative outcome among the adolescents in their sexual behaviours. Few mental health issues risk factors identified were peer pressure, limited sexual education and cyberbullying. Anxiety problem too may lead the social media users to perform negative sexual behaviour. ${ }^{49}$

\section{v. Pornography}

Pornography is closely related to internet and social media usage. The advancement of technology allows people to access pornography content via a smartphone. This access without supervision and control can lead to increase in pornography activities. It was found that majority of internet users admitted accessing pornography websites and content daily. ${ }^{3}$ Besides accessing pornographic material from the media, the 
adolescents also use social media to display their sexual content such as posting nude pictures of themselves. ${ }^{50}$ A study stated that pornography was stimulating and defined it as normal behaviour. ${ }^{3}$ Risk factors identified in this behaviour were lack of supervision from the adults, peer influences and lack of sexual educations.

\section{vi. Multiple online sexual partner}

The trend of seeking sexual partner is trending nowadays. Online dating that could end up with sexual activities among the social media users were commonly seen among the adults. It starts with the usual conversation then some of them abuse the social media platform for expressing their sexual behaviour. This act leads to sexting and may lead to sexual activity in real life. There are several social media applications used by irresponsible persons to seek multiple online sexual partner. ${ }^{31}$ This may lead to involvement in risky sexual behaviour. ${ }^{13}$ Not only do adolescents seek partners within their same age but also older than them. A study showed that adolescents use the social media to hook up with older people to engage in sexual activities. ${ }^{40}$ The advancement of technology in social media providing channels to seek partners online, coupled with lack of sexual education and supervision of these adolescents play a role in unwanted pregnancies resulting from risky sexual behaviour.

\section{DISCUSSION}

The findings in this systematic review shows that social media usage among adolescents have great impact on their sexual behaviour. With the increase of negative online sexual behaviour, adolescents are exposed to a greater risk of engaging in more online sexual activities which could lead to sexual intercourse. Besides, several other risk factors were identified that may attribute to the sexual behaviour of the adolescent.

Sexting is one of the sexual behaviours resulting from the usage of social media. This behaviour sparks from a simple message online sent among the adolescents which progresses to sexting activities. ${ }^{5}$ Without proper control of this behaviour, it can lead to more high-risk behaviours of the adolescents. Adolescence phase is vital due to their intense information seeking behaviour especially regarding sexual aspects of the social medias.
Lack of control and knowledge may lead this behaviour to more serious acts.

Pornography is another impact of social media usage among adolescents. Social media provides a huge amount of information that can easily be accessible where adolescents could be exposed to sexual content materials such as nude pictures, private part images and many more. $^{3}$ Peer pressure among adolescents predisposes them to pornography. Varied, unfiltered information from peers compare to parent or teachers may lead to misconception and addiction to pornography.

Online sex partner has also become a trend amongst the adolescents' social media users to satisfy their sexual curiosity. Online sex partners who progress to become physical multiple sex partners may lead to STD such as syphilis, gonorrhoea and even HIV disease. This can lead to greater health problems among the adolescents. Current trend shows the increasing behaviour of homosexuality such as gay.2,31 Adolescents who use social media inappropriately are at risk for such acts.

Mental health problem is also a significant impact of social media usage among adolescence. ${ }^{43}$ Addiction or dependency on social media in daily life may change the behaviour of the adolescents. Some adolescents may produce psychological symptoms such as narcissism, anxiety, popularity seekers and many more. Without further control and management, this can lead to more serious psychological issues such as major depression, paedophilia, psychosis and more. The relationship of the adolescent with the partner may be affected and end up with verbal or physical sexual abuse.

Sexual abuse and unsatisfied sexual desire are negative impacts of sexual behaviour related with the usage of social medias. ${ }^{11}$ The frequency of these behaviours is increasing with the advancement of technology.

Despite the negative impacts, some literature showed that social media usage among adolescents do provide some positive outcomes. A couple who use social media to interact with each other, result in a positive behavioural outcomes such as excitement and happiness between them. ${ }^{6}$ Some of the hook-up 
applications provide information that can increase the knowledge and awareness on STD and HIV transmission risk reduction. ${ }^{31}$ This information provides awareness on safe sex (eg: usage of condom) and prevention of unwanted pregnancy via contraception. ${ }^{40}$ Social media can also serve as a platform to search information regarding health, especially sexual health which gives benefit to the adolescents. ${ }^{1}$ Besides that, confidence level among adolescence in socializing skills can be improved with correct usage of social media. ${ }^{1}$

Several risk factors identified in the systematic review which are limited capacity of self-regulation, peer pressure, limited knowledge, no parental supervision and religiosity. These risk factors need to be identified and studied further in order to prevent any unwanted impacts from the usage of social media. ${ }^{1,43,49}$

Multidisciplinary approach needs to be carried out for the management of this issue. Family support and supervision are important to prevent adolescents from practising high-risk behaviours. ${ }^{12}$ The adolescents are usually eager to find new information and are likely to try new high-risk activities without thinking of the consequences. Thus, it is very important for adult supervision especially parents to monitor them. The government too plays a vital role. Law and policy should be strengthened to prevent any social media abuse by irresponsible individuals. Continuous monitoring of any suspicious activities within the social media platforms must be done to control the information that can be accessed by adolescents. Social media developers need to cooperate with the government to ensure the objectives of any social media platforms that is used especially by adolescents to be controlled in terms of sexual content. ${ }^{3}$ Nongovernmental organizations (NGOs), can also help to improve awareness and knowledge to the adolescents by conducting programs for adolescents to understand the possible impact of social media usage on their sexual behaviour. Providing support to adults empowers them to feel more confident in guiding young people through their cyber interactions. Online programs and apps may play a key role in reducing the harms associated with sexting by empowering young people and adults to have better conversations around safe sexting and digital safety. ${ }^{12}$

\section{ACKNOWLEDGEMENT}

This work receives support from The National University of Malaysia via GUP-2019-080.

\section{REFERENCES}

1. American College of O, Gynecologists' Committee on Adolescent Health C. Committee Opinion No. 653: Concerns Regarding Social Media and Health Issues in Adolescents and Young Adults. Obstet Gynecol. 2016;127(2):e62-5.

2. Arrington-Sanders R, Harper GW, Morgan A, Ogunbajo A, Trent M, Fortenberry JD. The Role of Sexually Explicit Material in the Sexual Development of Same-Sex-Attracted Black Adolescent Males. Archives of Sexual Behavior. 2015;44(3):597-608.

3. Pizzol D, Bertoldo A, Foresta C. Adolescents and web porn: a new era of sexuality. Int J Adolesc Med Health. 2016;28(2):169-73.

4. Kocturk N, Yuksel F. A Modern Danger for Adolescents: From Online Flirtation to Sexual Abuse. Dunsen Adam. 2018;31(3):294-300.

5. Pineda CO, Torres CA, Carreno TP, Rodriguez RA. Sexting And Its Relationship With Early Maladaptive Schemes In Adolescents. Rev Argent Clin Psicol. 2019;28(4):461-70.

6. Dir AL, Cyders MA. Risks, Risk Factors, and Outcomes Associated with Phone and Internet Sexting Among University Students in the United States. Archives of Sexual Behavior. 2015;44(6):1675-84.

7. Bianchi D, Morelli M, Baiocco R, Chirumbolo A. Sexting as the mirror on the wall: Bodyesteem attribution, media models, and objectified-body consciousness. Journal of Adolescence. 2017;61:164-72.

8. Rice E, Rhoades H, Winetrobe H, Sanchez M, Montoya J, Plant A, et al. Sexually Explicit Cell Phone Messaging Associated With Sexual Risk Among Adolescents. Pediatrics. 2012;130:66773. 
Prevalence and Characteristics of Youth

Sexting: A National Study. Pediatrics.

2011;129:13-20.

10. Houck C, Barker D, Rizzo C, Hancock E, Norton A, Brown L. Sexting and Sexual Behavior in At-Risk Adolescents. Pediatrics. 2014;133.

11. Morelli M, Bianchi D, Baiocco R, Pezzuti L, Chirumbolo A. Sexting, psychological distress and dating violence among adolescents and young adults. Psicothema. 2016;28(2):137-42.

12. Milton AC, Gill BA, Davenport TA, Dowling M, Burns JM, Hickie IB. Sexting, Web-Based Risks, and Safety in Two Representative National Samples of Young Australians: Prevalence, Perspectives, and Predictors. JMIR Ment Health. 2019;6(6):17.

13. Negriff S, Valente TW. Structural characteristics of the online social networks of maltreated youth and offline sexual risk behavior. Child Abuse Negl. 2018;85:209-19.

14. Over the Internet, under the Radar: Online Child Sexual Abuse and Exploitation - A Brief Literature [Internet]. 2017 [cited 10 June 2020]. Available from: http://www.barnardos.org.uk/ over_the_internet_under_the_radar_literature _review.pdf.

15. Cooper K, Quayle E, Jonsson L, Svedin C. Adolescents and self-taken sexual images: A review of the literature. Comput Hum Behav. 2016;55:706-16.

16. Brown C, Hegarty K. Digital dating abuse measures: A critical review. Aggression and Violent Behavior. 2018;40.

17. Borrajo E, Gámez-Guadix M, Calvete E. Cyber dating abuse: Prevalence, context, and relationship with offline dating aggression. Psychological reports. 2015;116.

18. Choi HJ, Van Ouytsel J, Temple J. Association between sexting and sexual coercion among female adolescents. Journal of Adolescence. 2016;53:164-8.

19. Doucette H, Collibee C, Hood E, Stone D, Dejesus B, Rizzo C. Perpetration of Electronic Intrusiveness Among Adolescent Females: Associations With In-Person Dating Violence. J Interpers Violence. 2018:088626051881572.
20. Dick RN, McCauley HL, Jones KA, Tancredi DJ, Goldstein S, Blackburn S, et al. Cyber dating abuse among teens using school-based health centers. Pediatrics. 2014;134(6):e1560-7.

21. Helweg-Larsen K, Schütt N, Larsen HB.

Predictors and protective factors for adolescent Internet victimization: results from a 2008 nationwide Danish youth survey. Acta Paediatr. 2012;101(5):533-9.

22. Mitchell K, Becker-Blease K, Finkelhor D. Inventory of Problematic Internet Experiences Encountered in Clinical Practice. Professional Psychology-research and Practice - PROF PSYCHOL-RES PRACT. 2005;36:498-509.

23. Sklenarova H, Schulz A, Schuhmann P, Osterheider M, Neutze J. Online sexual solicitation by adults and peers - Results from a population based German sample. Child Abuse Negl. 2018;76:225-36.

24. Epstein-Ngo QM, Roche JS, Walton MA, Zimmerman MA, Chermack ST, Cunningham RM. Technology-Delivered Dating Aggression: Risk and Promotive Factors and Patterns of Associations Across Violence Types Among High-Risk Youth. Violence Gend. 2014;1 (3):131-3.

25. Korchmaros J, Ybarra M, LanghinrichsenRohling J, Boyd D, Lenhart A. Perpetration of Teen Dating Violence in a Networked Society. Cyberpsychology, behavior and social networking. 2013;16.

26. Marganski A, Melander L. Intimate Partner Violence Victimization in the Cyber and Real World: Examining the Extent of Cyber Aggression Experiences and Its Association With In-Person Dating Violence. J Interpers Violence. 2015;33.

27. Reed L, Tolman R, Ward L. Gender matters: Experiences and consequences of digital dating abuse victimization in adolescent dating relationships. Journal of Adolescence. 2017;59:79-89.

28. Koops T, Dekker A, Briken P. Online sexual activity involving webcams-An overview of existing literature and implications for sexual boundary violations of children and adolescents. Behav Sci Law. 2018;36(2):182-97.

29. Van Ouytsel J, Walrave M, Ponnet K, Willems AS, Van Dam M. Adolescents' Perceptions of Digital Media's Potential to Elicit Jealousy, Conflict and Monitoring Behaviors Within Romantic Relationships. Cyberpsychology. 2019;13(3):21. 
30. Reed LA, Conn K, Wachter K. Name-calling, jealousy, and break-ups: Teen girls' and boys' worst experiences of digital dating. Children and Youth Services Review. 2020;108:104607.

31. Chan PA, Towey C, Poceta J, Rose J, Bertrand T, Kantor R, et al. Online hookup sites for meeting sexual partners among men who have sex with men in Rhode Island, 2013: a call for public health action. Public health reports. 2016;131(2):264-71.

32. Choi E, Wong J, Fong D. The use of social networking applications of smartphone and associated sexual risks in lesbian, gay, bisexual, and transgender populations: a systematic review. AIDS Care. 2016;29.

33. Krishnan A, Nguyen M, Giang LM, Ha TV, Bhadra M, Nguyen SM, et al. Finding Sex Partners Through Social Media Among Men Who Have Sex with Men in Hanoi, Vietnam. J Community Health. 2018;43(1):146-56.

34. Luo Q, Wu Z, Chen Z, Ma Y, Mi G, Liu X, et al. App use frequency and condomless anal intercourse among men who have sex with men in Beijing, China: a cross-sectional study. Int J STD AIDS. 2019;30(12):1146-55.

35. Holloway IW, Rice E, Gibbs J, Winetrobe H, Dunlap S, Rhoades H. Acceptability of smartphone application-based HIV prevention among young men who have sex with men. AIDS Behav. 2014;18(2):285-96.

36. Macapagal K, Coventry R, Puckett JA, Phillips G, 2nd, Mustanski B. Geosocial Networking App Use Among Men Who Have Sex With Men in Serious Romantic Relationships. Arch Sex Behav. 2016;45(6):1513-24.

37. Wiele CVD, Tong ST. Breaking boundaries: the uses \& gratifications of grindr. Proceedings of the 2014 ACM International Joint Conference on Pervasive and Ubiquitous Computing. 2014.

38. Landovitz RJ, Tseng CH, Weissman M, Haymer M, Mendenhall B, Rogers K, et al. Epidemiology, sexual risk behavior, and HIV prevention practices of men who have sex with men using GRINDR in Los Angeles, California. J Urban Health. 2013;90(4):729-39.

39. Lorimer K, Flowers P, Davis M, Frankis J. Young men who have sex with men's use of social and sexual media and sex-risk associations: cross-sectional, online survey across four countries. Sex Transm Infect. 2016;92(5):371-6.

40. Macapagal K, Moskowitz DA, Li DH, Carrion A, Bettin E, Fisher CB, et al. Hookup App Use, Sexual Behavior, and Sexual Health Among Adolescent Men Who Have Sex With Men in the United States. J Adolesc Health. 2018;62 (6):708-15.

41. Bianchi D, Morelli M, Baiocco R, Chirumbolo A. Psychometric properties of the Sexting
Motivations Questionnaire for adolescents and young adults. Rassegna Di Psicologia.

2016;XXXV:5-18.

42. Chen LJ, Yang Y, Su WL, Zheng LJ, Ding C, Potenza MN. The relationship between sexual sensation seeking and problematic Internet pornography use: A moderated mediation model examining roles of online sexual activities and the third-person effect. Journal of Behavioral Addictions. 2018;7(3):565-73.

43. Marino C, Hirst C, Murray C, Vieno A, Spada MM. Positive mental health as a predictor of problematic internet and Facebook use in adolescents and young adults. Journal of Happiness Studies. 2018;19(7):2009-22.

44. Jin SV, Ryu E. "The Paradox of Narcissus and Echo in the Instagram Pond" in Light of the Selfie Culture from Freudian Evolutionary Psychology: Self-Loving and Confident but Lonely. Journal of Broadcasting \& Electronic Media. 2018;62(4):554-77.

45. Withers KL, Parrish JL, Terrell S, Ellis TJ. The relationship between the "dark triad" personality traits and deviant behavior on social networking sites. 2017.

46. Fongkaew W, Fongkaew K. My space, my body, my sexual subjectivity: social media, sexual practice and parental control among teenage girls in urban Chiang Mai. Culture, health \& sexuality. 2016;18(5):597-607.

47. MS Hanani Nabilah, IZA Noor Dalila, D Faiz. Systematic Review of Child Abuse Perpetrators Worldwide: A Characteristic and Risk Factors. Journal of Health and Translatinal Medicine. 2019;22(1):41-49.

48. Tiggemann M, Slater A. A Test of Objectification Theory in Former Dancers and Non-Dancers. Psychology of Women Quarterly. 2001;25:57-64.

49. Naezer M. From risky behaviour to sexy adventures: reconceptualising young people's online sexual activities. Cult Health Sex. 2018;20(6):715-29.

50. Burkhart L, Hoopes A, Moreno M. " Why is this person writing this stuff on Facebook?" Female college students' perceptions of sexual reference displays on Facebook. College Student Journal. 2017;51(3):337-46. 